\title{
Immunological Indicators in Dogs Affected by Deep Pyoderma
}

\author{
F. ŠPRUČEK ${ }^{1}$, M. TOMAN ${ }^{2,3}$, M. FALDYNA ${ }^{2,3}$, M. SVOBODA ${ }^{3}$ \\ ${ }^{1}$ Small Animal Clinic, Olomouc, Czech Republic \\ ${ }^{2}$ Veterinary Research Institute, Brno, Czech Republic \\ ${ }^{3}$ University of Veterinary Medicine and Pharmaceutical Sciences, Brno, Czech Republic
}

Received September 8, 2006

Accepted February 20, 2007

\begin{abstract}
Špruček F., M. Toman, M. Faldyna, M. Svoboda: Immunological Indicators in Dogs Affected by Deep Pyoderma. Acta Vet. Brno 2007, 76: 283-290.

We examined the immune state of dogs with deep pyoderma to elucidate the relationship between clinical symptoms and immunological processes. We measured selected immunological parameters in control dogs $(n=10)$ and dogs of various breeds (German Shepherds were not included) affected by deep pyoderma $(n=25)$. We found that the affected dogs had increased relative counts of neutrophils, decreased relative and absolute counts of lymphocytes, higher relative counts of CD3+ lymphocytes and CD8+ lymphocytes but lower relative counts of CD21+ lymphocytes and CD4+ lymphocytes. The affected dogs exhibited a reduced activity of nonstimulated as well as mitogen-stimulated lymphocytes. Lower values of circulating immune complexes (CIC) in affected dogs were conditioned by the young age of animals. Nevertheless, the changes found in our study were not expressed in all animals.
\end{abstract}

Flow cytometry, CD antigens, lymphocyte activity, immunocomplexes, immume system, dog, deep pyoderma

Typically, deep pyoderma is often considered as secondary clinical symptoms of diseases with a different causation, accompanied by bacterial colonisation of damaged skin (Mas on 1991; Chabanne et al. 2000; Scott et al. 2001). Bacterial microflora, especially pathogenic staphylococci and streptococci, deepen the primary pathogenic process by producing toxins, exogenous superantigens (Foster 2004; Hnilica and May 2004). Toxins, including staphylococcal enterotoxin and toxic shock syndrome toxins, manifest themselves by an increased temperature, hypotension and oliguria. As a result of the superantigen effect, the $\mathrm{TNF} \propto$ and IL-2 cytokines are massively released from $\mathrm{T}$ lymphocytes. There are also superantigens activating the $\mathrm{B}$ lymphocyte system in response to staphylococcal protein $\mathrm{A}$, which is part of the bacterial wall and is able to interact with immunoglobulin Fc fragment (Denerolle et al. 1998).

The studies dealing with the activities of bacterial toxins that directly influence the immune system have shown that superantigens of a microbial origin stimulating the $\mathrm{T}$ lymphocytes did not require prior primary contacts and were not retained in the immune memory (Hendricks et al. 2002; Hnilica and May 2004). The immune response to superantigen results in overproduction of cytokines IL-2 which leads to the suppression of immune responses. At the same time, superantigens stimulate CD4+ and CD8+ subpopulations of T-lymphocytes. These studies suggest that bacterial toxins affect an array of patho-immunological parameters which may impinge on the disease process and the overall therapeutic result.

Deep pyoderma of German Shepherds is known to be associated with marked alteration of immune status of affected dogs (Chabanne et al. 1995; Toman et al. 1997; Denerolle et al. 1998). However, there is only little information about impairment of immune system in deep pyoderma of other breeds (Tom an et al. 1998). Therefore, the objective of the study

Address for correspondence:

MVDr. František Špruček

Veterinární klinika pro psy a kočky

Tylova 3

Phone: +420602705362

77900 Olomouc, Czech Republic

E-mail: sprucek@email.c

http://www.vfu.cz/acta-vet/actavet.htm 
was to evaluate the relationship between the clinical symptoms of deep pyoderma and the levels of cellular immunity and serum factors in affected dogs. The knowledge of processes occurring at the onset of the disease could considerably improve our understanding and the resulting therapeutic success in treating dermal diseases.

\section{Materials and Methods}

Animals

Immunological indicators were investigated using standard methods in 35 dogs of various breeds (14 breeds), ages (mean $=6$ years, ranging from 2 to 10 years), and both sexes (18 males and 17 females), of which 25 suffered from deep pyoderma. We further divided the treated group with the symptoms of pyoderma into two groups by their therapeutic history: one group with the first appearance of the disease $(n=11)$, and another with the idiopatic recurrent deep pyoderma for which the dogs were already treated in the past by antibiotics or glucocorticoids, or a combination of both $(n=14)$. We examined dogs from both groups for immunological indicators before the therapy had started and no significant difference was found between the two groups. From the latter group, we chose a subset of individuals $(n=9)$ treated only by corticosteroids. Their therapy was terminated 4 to 5 weeks before collecting blood samples. The control group consisted of 10 randomly chosen individuals without any clinical symptoms of dermatological disease.

\section{Sample collection}

Blood samples were collected from the v. cephalica antebrachii. Samples for immunofenotyping and for detection of cell activity were taken into heparinized test tubes (10 IU per $\mathrm{ml}$ ), the remaining into tubes with coagulation granules. The blood samples were analysed within 3 hours after collection.

Total and differential leukocyte counts

The total leukocyte count was determined using the Digicell 500 cell counter (Contraves AG, Switzerland). The differential leukocyte count was calculated from blood smears stained with May-Grünwald and GiemsaRomanowski. Lymphocyte subsets were counted by flow cytometry using an indirect whole-blood lysis technique as described previously (Faldy na et al. 2001a). Monoclonal antibodies against canine CD3 (CA17.2A12, IgG1), CD4 (CA13.1E4, IgG1), CD8 (CA9.JD3, IgG2a), CD21 (CA 2.1D6, IgG1), TCRgd (CA20.8H1, IgG2a), CD45 (CA12.10C12, IgG1) and CD45RA (CA4.1D3, IgG1) were a generous gift from Prof. P. F. Moore (School of Veterinary Medicine, University of California, USA). Data were acquired on a standard FACSCalibur ${ }^{\mathrm{TM}}$ flow cytometer (Becton Dickinson, Mountain View, CA).

\section{Lymphocyte transformation test}

The activity of lymphocytes was determined using the lymphocyte transformation test as described previously (Toman et al. 1998; Faldy na et al. 2001b). Briefly, the density of the cell suspension was adjusted to $10^{6}$ per ml of RPMI 1640 medium (Sigma, St Louis) supplemented with 10\% precolostral calf serum, 100000 U/l penicillin and $0.2 \mathrm{~g} / \mathrm{l}$ streptomycin. The suspension of $200 \mu \mathrm{l}$ was transferred per well of a 96 -well flat-bottomed microtitre plate. Mitogenic lectins were used at the following concentrations: phytohaemagglutinin (PHA) $-40 \mathrm{mg} / \mathrm{ml}$, concanavalin A (ConA) - 10 or $2.5 \mathrm{mg} / \mathrm{ml}$, pokeweed mitogen (PWM) - $10 \mathrm{mg} / \mathrm{ml}$. All samples were run in triplicate. The microplates were incubated at $37{ }^{\circ} \mathrm{C}$ with $5 \% \mathrm{CO}_{2}$ for 3 days. Twenty hours before harvesting, $50 \mathrm{ml}$ medium with ${ }^{3} \mathrm{H}$-thymidine $(5 \mathrm{mCi} / \mathrm{ml})$ was added. The incorporation of ${ }^{3} \mathrm{H}$-thymidine was measured with a liquid scintillation counter (Packard Tricarb CA 1600, Canberra-Packard Instruments). The stimulation index (S.I.) was calculated as the ratio of counts per minute (CPM) in stimulated samples versus CPM in non-stimulated controls.

\section{Phagocytosis assays}

Phagocytosis of metacrylate particles by neutrophils and monocytes was assessed in whole blood using a modification of the test described by Vetvicka et al. (1982). The percentage of cells in which at least three particles were engulfed was assessed as blood smears after 1 hour incubation.

The metabolic activity of neutrophils and monocytes was evaluated on the basis of chemiluminescence after the reaction with luminol (Allen et al. 1972). The tests were carried out using non-activated cells (spontaneous chemiluminescence) and cells activated with rice starch (activated chemiluminescence). The respiratory burst index was defined as a ratio of the peaks of activated to spontaneous chemiluminescence.

Total serum immunoglobulin concentrations

Total serum immunoglobulin concentrations were determined by turbidimetric assay resulting from the addition of zinc sulphate to serum. The procedure was a modification of the method described by McEwan et al. (1970).

Serum lysozyme activity

Serum lysozyme activity was determined by spectrophotometric measurement of density of a Micrococcus lysodeicticus suspension in test tubes after an addition of a serum sample. The densities of bacterial suspensions were measured by the spectrophotometer Specol 11 (Carl Zeiss, Jena). Optical density readings were converted to lysozyme concentration values $(\mathrm{mg} / \mathrm{l})$ using a standard curve which was determined from serial dilutions of the lysozyme (Sigma). 
Circulating immune complexes (CIC)

The concentrations of CIC in the serum samples were determined using nephelometric measurement of soluble antigen-antibody complexes after their precipitation with polyethylene glycol (PEG) as described by Haskova (1986). The difference between the densities of control and sample suspensions was measured by Specol 11 (Carl Zeiss Jena). The results were expressed in terms of absorbance multiplied by a factor of one thousand (marked as unit - U).

Statistical analysis

The significance of differences between the indicator means in dogs affected by the deep pyoderma and the control animals was tested by $t$-test. In each test, we checked for the equality of variances. If proved unequal, we used the Welch analysis of variance for testing. The differences in percentages were analysed by non-parametric Wilcoxon test. Furthermore, we examined to what extent the treated animals form a homogenous group with respect to the previous therapy by corticosteroids. Both the dogs with the first occurrence of pyoderma and those with recurrent pyoderma were compared to the control group $(n=10)$. We used analysis of variance to test for $\mathrm{H}_{0}(=$ no differences) in these three groups of animals. In case of inequality in variances, we applied the Welch modification of analysis of variance again. When the hypothesis $\mathrm{H}_{0}$ was rejected, we tested for differences between the means using Dunnett's test, specifically designed for multiple comparisons with the control animals. The proportions, such as the values of differential blood counts, were analysed using non-parametric Kruskal-Wallis test (K-W test) for comparisons of more than two samples. The relationship between the quantitative variables was analysed by a linear regression method. We used the program JMP for all statistical analyses (SAS Institute Inc. 2005).

\section{Results}

The dogs affected by deep pyoderma had significantly lower actual and relative counts of lymphocytes than the control animals, and relatively more neutrophils than the controls (Table 1). Applying a flow cytometry, we found significantly higher relative counts of CD3+ T-lymfocytes and CD8+ Tc- lymphocytes in dogs affected by deep pyoderma compared to control animals (Table 2). In contrast, relative counts of CD21+ B-lymphocytes were decreased. The detailed comparisons of dogs with different therapeutic histories to controls showed that the dogs with recurrent pyoderma treated repeatedly by corticosteroids $(n=9)$ 4 to 6 weeks prior to the collection of blood samples had lower relative counts of CD4+ Thlymphocytes than the controls (Dunnett's test, $P=0.048$ ). There were no differences in other parameters. Comparison of all dogs with deep pyoderma $(n=25)$ revealed only marginally significant higher relative counts CD4+ Th-lymphocytes compared to control dogs (Wilcoxon test: $P=0.067$ ).

Table 1. Relative and absolute counts of leukocytes $( \pm \mathrm{SD})$ measured in control dogs and dogs affected by deep pyoderma

\begin{tabular}{|l|c|c|c|c|c|}
\hline & & Controls & Deep pyoderma & & \\
\hline Indicator & Units & $(\mathrm{n}=10)$ & $(\mathrm{n}=25)$ & $t / \mathrm{Z}$ & $P$ \\
\hline Leukocytes & $10^{9} / 1$ & $11.25 \pm 1.72$ & $12.34 \pm 1.09$ & 0.54 & 0.60 \\
\hline Lymphocytes & $10^{9} / 1$ & $3.33 \pm 1.28$ & $2.39 \pm 0.88$ & 2.28 & 0.029 \\
\hline Neutrophils & $10^{9} / 1$ & $6.80 \pm 1.47$ & $8.39 \pm 0.93$ & 1.14 & 0.26 \\
\hline Monocytes & $10^{9} / 1$ & $0.49 \pm 0.18$ & $0.64 \pm 0.11$ & 0.68 & 0.50 \\
\hline Eosinophils & $10^{9} / 1$ & $0.63 \pm 0.10$ & $0.45 \pm 0.06$ & 1.59 & 0.12 \\
\hline Lymphocytes & $\%$ & $29.0 \pm 2.7$ & $22.4 \pm 1.7$ & 2.13 & 0.041 \\
\hline Neutrophils & $\%$ & $61.0 \pm 2.7$ & $68.0 \pm 1.7$ & 2.54 & 0.015 \\
\hline Monocytes & $\%$ & $4.2 \pm 0.7$ & $4.6 \pm 0.5$ & 0.49 & 0.62 \\
\hline Eosinophils & $\%$ & $6.1 \pm 0.9$ & $4.2 \pm 0.6$ & 1.67 & 0.10 \\
\hline
\end{tabular}

Statistical significance of differences in absolute counts was evaluated by t-test $(t)$, the significance of differences in relative counts was assessed by the nonparametric Wilcoxon test ( $Z$ ) using normal approximation. $P$ indicates a probability value associated with test statistics.

Control and pyoderma dogs did not differ in variables indicative of the rate of phagocytosis (Table 3). 
Table 2. Relative and actual counts of $C D$ antigens lymphocytes $( \pm \mathrm{SD})$ measured in control dogs and dogs affected by deep pyoderma, counted by flow cytometry

\begin{tabular}{|c|c|c|c|c|c|c|}
\hline & & & Controls & $\begin{array}{c}\text { Deep } \\
\text { pyoderma }\end{array}$ & & \\
\hline Lymphocytes & CD antigen & Units & $(n=10)$ & $(n=25)$ & $t / Z$ & $P$ \\
\hline T-lymphocytes & CD3+ & $\%$ & $64.5 \pm 22.3$ & $83.5 \pm 11.2$ & 3.29 & 0.0025 \\
\hline Th- subset & CD4+ & $\%$ & $40.5 \pm 11.8$ & $47,3 \pm 8.2$ & 1.90 & 0.067 \\
\hline Tc-subset & CD8+ & $\%$ & $14 \pm 6$ & $20.1 \pm 9.1$ & 2.12 & 0.041 \\
\hline DP-subset & CD4+8+ & $\%$ & $0.91 \pm 0.5$ & $1.4 \pm 1.0$ & 2.42 & 0.13 \\
\hline NK-subset & CD3-8+ & $\%$ & $0.41 \pm 0,3$ & $0.32 \pm 0.3$ & 0.63 & 0.53 \\
\hline$\gamma \delta$-TCR subset & CD3+4-8- & $\%$ & $2.55 \pm 1.1$ & $3.22 \pm 2.3$ & 0.88 & 0.39 \\
\hline B-lymphocytes & CD21+ & $\%$ & $34 \pm 21$ & $20.2 \pm 8.8$ & 2.10 & 0.011 \\
\hline $\mathrm{T} / \mathrm{B}$ & $\mathrm{CD} 3 / \mathrm{CD} 21$ & ratio & $3.39 \pm 2.8$ & $5.38 \pm 3.7$ & 1.51 & 0.14 \\
\hline $\mathrm{Th} / \mathrm{Tc}$ & CD4+/CD8+ & ratio & $3.30 \pm 1.2$ & $2.74 \pm 1.3$ & 1.14 & 0.26 \\
\hline T-lymphocytes & CD3+ & $10^{6} / 1$ & $1850 \pm 550$ & $2057 \pm 845$ & 0.71 & 0.49 \\
\hline Th- subset & CD4+ & $10^{6} / 1$ & $1187 \pm 360$ & $1168 \pm 509$ & 0.11 & 0.92 \\
\hline Tc-subset & CD8+ & $10^{6} / 1$ & $393 \pm 130$ & $474 \pm 207$ & 1.13 & 0.27 \\
\hline DP-subset & $\mathrm{CD} 4+8+$ & $10^{6} / 1$ & $24.8 \pm 13.3$ & $33.9 \pm 25.4$ & 1.06 & 0.30 \\
\hline NK-subset & CD3-8+ & $10^{6} / 1$ & $13.7 \pm 8.9$ & $8.5 \pm 7.3$ & 1.76 & 0.09 \\
\hline$\gamma \delta$-TCR subset & CD3+4-8- & $10^{6} / 1$ & $71.1 \pm 40.5$ & $89.2 \pm 81.5$ & 0.66 & 0.51 \\
\hline B-lymphocytes & CD21+ & $10^{6} / 1$ & $1131 \pm 1087$ & $582 \pm 538$ & 1.52 & 0.16 \\
\hline
\end{tabular}

Statistical significance of differences in absolute counts was evaluated by t-test $(t)$, the significance of differences in relative counts was assessed by the nonparametric Wilcoxon test ( $Z$ ) using normal approximation. $P$ indicates a probability value associated with test statistics.

Table 3. Relative and actual counts of phagocyting cells and chemiluminescence $( \pm \mathrm{SD})$ measured in control dogs and dogs affected by deep pyoderma

\begin{tabular}{|l|c|c|c|c|c|}
\hline & & Controls & Deep pyoderma & & \\
\hline Indicator & Units & $(\mathrm{n}=10)$ & $(\mathrm{n}=25)$ & $t / \mathrm{Z}$ & $P$ \\
\hline Phagocytosis dif. & $\%$ & $68.9 \pm 4.7$ & $72.9 \pm 2.9$ & 0.74 & 0.47 \\
\hline Phagocytosis abs. & $10^{6} / 1$ & $4973 \pm 1056$ & $6580 \pm 668$ & 1.28 & 0.21 \\
\hline Chl. - spont. B & $\mathrm{mV}$ & $2.4 \pm 0.9$ & $3.2 \pm 0.5$ & 0.83 & 0.42 \\
\hline Chl. - activ. B $^{1}$ & SI & $74.8 \pm 11.9$ & $89.7 \pm 7.5$ & 1.06 & 0.30 \\
\hline SI M $^{2}$ & SI & $57.3 \pm 12.9$ & $41.8 \pm 8.2$ & 1.03 & 0.31 \\
\hline SI I & SI & $68.4 \pm 9.7$ & $47.8 \pm 6.1$ & 1.78 & 0.08 \\
\hline
\end{tabular}

${ }^{1}$ Chemiluminescence spontaneous, ${ }^{2}$ SI M- stimulation index (maximum), ${ }^{3}$ SI I- stimulation index (integral).

The activity of non-stimulated lymphocytes as determined by lymphocyte transformation test was lower in affected dogs than that in control dogs (Table 4). The dogs with pyoderma also showed a decreased response of lymphocytes in vitro to the stimulation by PHA 1 , Con.A 2 and PWM 1 lectins.

The dogs affected by pyoderma exhibited lower levels of CIC than the controls (Table 5, Fig. 1a). However, the levels of CIC were conditioned by age of animals, i.e., the difference is significant for young animals only (interaction $\mathrm{CIC} \times$ age, $F_{1,31}=6,81, P=0.014$ ). While in control animals the levels of CIC decreased with age, those in the affected dogs were low for all ages (Fig. 1b). Other serological indicators did not differ significantly between control and affected animals (Table 5).

\section{Discussion}

Several studies have suggested the link between dermatological diseases and immunological processes (Barta and Turnwald 1983; Mason 1991; Toman et al. 
Table 4. Average counts (mean $\pm \mathrm{SD}$ ) for indicators characterising incident blastic transformation of lymphocytes in control dogs and dogs affected by deep pyoderma

\begin{tabular}{|l|c|c|c|c|c|}
\hline & & Controls & Deep pyoderma & & $t$ \\
\hline $\begin{array}{l}\text { Indicator } \\
\text { transformation }\end{array}$ & Units & $(\mathrm{n}=10)$ & $(\mathrm{n}=25)$ & 2.13 & 0.042 \\
\hline $\begin{array}{l}\text { lymph. stimulation } \\
\text { with PHA }\end{array}$ & $\mathrm{CPM}$ & $221 \pm 35.3$ & $133 \pm 22.3$ & 2.49 & 0.018 \\
\hline Con A & CPM & $9893 \pm 1436$ & $3663 \pm 909$ & 1.96 & 0.06 \\
\hline Con A & CPM & $55801 \pm 1188$ & $12257 \pm 1762$ & 3.04 & 0.0049 \\
\hline PWM & CPM & $5069 \pm 813$ & $2565 \pm 536$ & 2.57 & 0.015 \\
\hline PHA & SI & $34.7 \pm 10$ & $30.0 \pm 6.3$ & 0.39 & 0.67 \\
\hline Con A (opt. dose) & SI & $49.3 \pm 7.9$ & $46.4 \pm 12.5$ & 0.19 & 0.85 \\
\hline Con A (subopt dose) & SI & $57.1 \pm 9.3$ & $47.8 \pm 6.3$ & 0.83 & 0.41 \\
\hline PWM & SI & $24.0 \pm 3.2$ & $22.5 \pm 4.9$ & 0.26 & 0.80 \\
\hline
\end{tabular}

$\mathrm{SI}=$ stimulation index, $\mathrm{CMP}=$ counts per minute, ${ }^{1}$ lymphocyte transformation test,

${ }^{2}$ lymphocyte stimulated with mitogenic lectins, ${ }^{3} \mathrm{ConA}-$ optim. dose 10 or suboptim dose $2.5 \mu \mathrm{g} / \mathrm{ml}$,
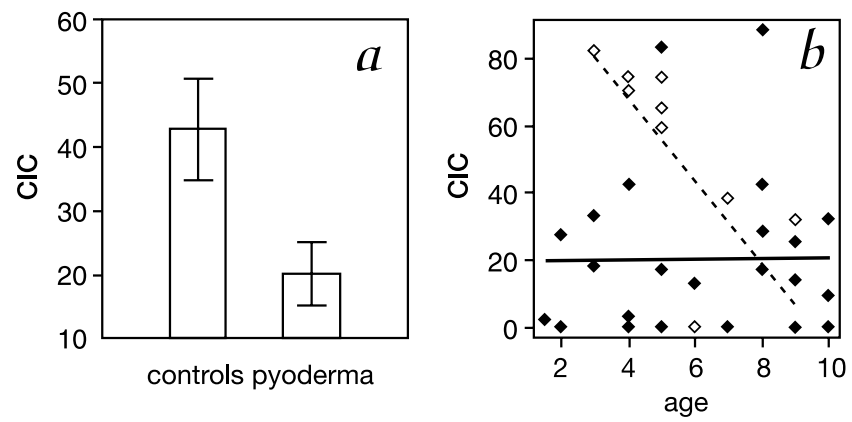

Fig. 1. a) Least square means of circulating immune complexes (CIC) levels (for control dogs and dogs affected by deep pyoderma. The results were expressed in terms of absorbance multiplied by a factor of one thousand. The bars indicate SE. b) Linear models for circulating immune complexes levels as depending on age in control dogs (dotted line) and dogs affected by deep pyoderma (solid line). The circles denote the observed data for control (open) and affected dogs (closed).

Table 5. Serological factors (mean \pm SD) measured in control dogs and dogs affected by deep pyoderma

\begin{tabular}{|l|c|c|c|c|c|}
\hline & & Controls & Pyoderma & & \\
\hline Indicator & Units & $(\mathrm{n}=10)$ & $(\mathrm{n}=25)$ & $t$ & $P$ \\
\hline Total protein & $\mathrm{g} / 1$ & $77.9 \pm 4.1$ & $75.8 \pm 2.6$ & 0.43 & 0.43 \\
\hline Immunoglobulin & $\mathrm{g} / 1$ & $7.4 \pm 0.8$ & $8.4 \pm 0.5$ & 1.16 & 0.25 \\
\hline CIC (PEG) 1 & arab.units & $49.4 \pm 8.2$ & $20.2 \pm 5.2$ & 3.02 & 0.0049 \\
\hline Lysozyme & $\mathrm{g} / 1$ & $2.4 \pm 1.2$ & $5.1 \pm 0.8$ & 3.40 & 0.07 \\
\hline
\end{tabular}

${ }^{1} \mathrm{CIC}=$ Circulating immune complexes $(\mathrm{PEG}=$ polyethylene glycol precipitation test $)$

1997, 1998; Nickoloff and Stevens 2006); however, detailed information on immunological response is still missing. Here we present blood indicators characterising cellular and humoral immunity in dogs with deep pyoderma prior to the treatment. By examining more than 40 variables, we found that the affected dogs had increased relative counts of neutrophils and decreased relative and actual counts of lymphocytes. They were also characterised by higher relative counts of CD3+ lymphocytes and CD8+ lymphocytes but lower relative counts of CD21+ lymphocytes and CD4+ lymphocytes. 
The affected dogs had a reduced activity of non-stimulated and mitogen-stimulated lymphocytes. They also exhibited lower values of CIC; however, these were conditioned by young age. Nevertheless, the changes found in our study were not expressed in all animals.

The observation of increased counts of neutrophils and decreased counts of lymphocytes in dogs affected by deep pyoderma corresponds to previous findings (Denerolle et al. 1998; T o man et al. 1998). While the former is most likely a direct result of chronic bacterial inflammation of skin, the latter could be a consequence of immunosuppressive effects of bacterial superantigens ( $\mathrm{B}$ arta and Turnwald 1983). This may suggest that at least some immune processes are involved in pathological processes associated with canine deep pyoderma.

We showed that the proportions of CD3+ T-lymphocytes and CD8+ Tc-lymphocytes were increased and that of CD21+ B-lymphocytes were decreased. The decrease of CD4+ Thlymphocytes was observed only in dogs with recurrent pyoderma in which the therapy by glucocorticoids was terminated 4 - 6 weeks before collection and analysis of blood samples. Most likely, Th-lymphocytes in this group of dogs were immunosuppressed and this effect of glucocorticoids persisted for more than one month. Generally, these findings agree well with those described in German shepherd dogs (Chabanne et al. 1995; Denerolle et al. 1998); however, changes in $\mathrm{T}$ and $\mathrm{B}$ cells have been observed in dogs without dermatological symptoms as well, which may be indicative of immunodeficiency of a primary origin. Some of the autoimmune diseases, e.g. systemic lupus erythematosus, are accompanied by absolute and relative decreases in CD8+ Tc-lymphocytes and increases in CD4+ Th-lymphocytes, which fact may be helpful in discriminating among causes of recurrent deep pyodermas (Chabanne et al. 2000). Monitoring of the response of Tclymphocyte counts to therapy may therefore be of certain value when evaluating its effectiveness (Chabanne et al. 2000).

The dogs with pyoderma exhibited a reduced activity of non-stimulated as well as mitogen-stimulated lymphocytes. Lymphocyte transformation test measures the in vitro ability of lymphocytes to transform into blasts in response to various non-specific mitogens. The decreased activity of lymphocytes in transformation test has been reported for German shepherds affected by deep pyoderma (Miller 1991; Toman et al. 1997, 1998).

We also recorded low values of CIC in the young dogs affected by pyoderma when compared to control dogs. The age-related changes in CIC levels are rarely reported. In mice, the level of CIC was observed to increase with age and the caloric content in diet (SafaiKutti et al. 1980). This is the opposite of what we observed in dogs. Clearly, we need more data on physiological effects of individual properties on immunocomplexes in different organisms. Immunocomplexes form frequently during chronic infectious diseases and activate a complement damaging the tissues. This may be one of the potential causes of recurrent deep pyoderma (Deboer 1988).

We conclude that the immune processes, as judged by differences in values of immunological indicators, are involved in the canine deep pyoderma but that the overall changes in the immune system are weak. There is little hope that these differences can be of diagnostic value in clinical practice. However, this is not to say that further progress in studying immunological processes in connection with dermatological diseases is precluded. In particular, deep pyoderma is not among clear nosological entities, arising from different causes and mechanisms. Further differentiation between pyoderma, based on a deeper understanding of the primary pathogenic processes, may lead to better interpretable results and thus shed more light on the role of the immune system in skin diseases. 


\section{Úroveň imunologických ukazatelů u psů s hlubokou pyodermií}

Imunologická studie byla zaměřena na psy s idiopatickou hlubokou pyodermií v období let 2002 - 2006. Bylo sledováno 35 psů různých plemen jiných než němečtí ovčáci, z toho 25 psů s klinickými příznaky hluboké pyodermie a 10 klinicky zdravých psů jako kontroly. Bylo provedeno vyšetření vybraných imunologických ukazatelů před zahájením vlastní léčby, deset dní po odčervení. Psi s pyodermií vykazovali signifikantní absolutní $\left(10^{9} / 1\right)$ a relativní (\%) snížení lymfocytů a relativní zvýšení neutrofilů. Průtokovou cytometrií bylo zjištěno signifikantní zvýšení relativního zastoupení CD3+ T-lymfocytů a to subpopulace CD8+ Tc-lymfocytů a snížení relativního počtu CD21+ B-lymfocytů. Signifikantní snížení relativního počtu CD4+ Tc-lymfocytů bylo zjištěno pouze u psů s hlubokou pyodermií, kteří byli léčeni před 4 - 6 týdny glukokortikoidy. Hodnoty nestimulovaných lymfocytů v testu blastická transformace u nemocných psů vykazovaly sníženou aktivitu ve srovnání s kontrolami a sníženou odpověd lymfocytů in vitro na stimulaci mitogeny. Rozdíly v hodnotách CIK mezi skupinou s hlubokou pyodermií a kontrolami byly závislé na věku zvířat. Protože u zdravých jedinců hodnoty CIK výrazně klesaly s věkem, nižší hodnoty byly u psů s pyodermií pozorovány jen u nejmladších jedinců.

\section{Acknowledgement}

We thank Lenka Levá for laboratory processing of blood samples and Emil Tkadlec for help with statistical analysis of data. This work was partly supported by the project Mze 0002617201 .

\section{References}

ALLEN RC, SIJENHOLM RI, STEELE RH 1972: Evidence for the generation of an electronic excitation state in human polymorphonuclear leukocytes and its participation in bactericidal activity. Biochem Biophys Res Commun 47: 679-685

BARTA O, TURNWALD GH 1983: Demodicosis, pyoderma, and other skin diseases of young dogs, and their associations with immunological dysfunctions. Comp Cont Educ Pract Vet 5: 995- 1003

CHABANNE L, BONNEFONT C, BERNAUD J, RIGAL D 2000: Clinical applications of flow cytometry and cell immunophenotyping to companion animals (dog and cat). Methods Cell Sci 22: 199-207

CHABANNE L, MARCHAL T, DENEROLLE P, MAGNOL JP, FOURNEL C, MONIER JC, RIGAL D 1995: Lymphocyte subset abnormalities in German shepherd dogs pyoderma (GSP). Vet Immunol Immunopathol 49: 189-198

CHAMMAS PPC, HAGIWARA MK 1998: Evaluation of neutrophilic function (chemotaxis, phagocytosis and microbicidal activity) in healthy dogs and in dogs suffering from recurrent deep pyoderma. Vet Immunol Immunopathol 64: 123-131

DAY MJ 2005: Cytokines and cytokine therapy in small animal medicine. $28^{\text {th }}$ WVA Congres of Minneapolis

DEBOER DJ, IHRKE PJ, STANNARD AA 1988: Circulation immune complex concentrations in selected cases of skin disease in dogs. Am J Vet Res 49: 143-146

DENEROLLE P, BOURDOISEAU G, MAGNOL JP, ULPAT C, CHABANNE L 1998: German Shepherd dog pyoderma: a prospective study of 23 cases. Vet Dermatol 9: 243-248

FALDYNA M, LEVA L, KNOTIGOVA P, TOMAN M 2001a: Lymphocyte subsets in peropheral blood of dogs - a flow cytometric study. Vet Immunol Immunopathol 82: 23-37

FALDYNA M, LAZNICKA A, TOMAN M 2001b: Immunosupression in bitches with pyometra. J Small Anim Pract 45: 5-10

FOSTER AP 2004: Immunomodulation and immunodeficiency. Vet Dermatol 15: 115-126

HAŠKOVÁ V 1986: Průkaz cirkulujících imunokomplexů. In: Vybrané Diagnostické Metody Lékařské Imunologie. Eds: PROCHÁZKOVÁ J, JOHN AC, Avicenum, Praha, pp. 114-119

HNILICA KA, MAY E 2004: Staphylococcal pyoderma: an emerging problem. Compend Cont Educ Pract Vet 26: 560-561

HOLM BR 2003: Efficacy of milbemycin oxime in the treatment of canine generalized demodicosis: a retrospective study of 99 dogs (1995 - 2000). Vet Dermatol 14: 189-195

JACKSON HA, OLIVRY T, BERGET F, DUNSTON SM, BONNEFONT C, CHABANNE L 2004: Immunopathology of vesicular cutaneous lupus erythematosus in the rough collie and Shetland sheepdog: a canine homologue of subacute cutaneous lupus erythematosus in humans. Vet Dermatol 15: 230-239

MASON IS 1991: Canine Pyoderma. J Small Anim Pract 32: 381-386

MAKIMURA S, SAWAKI M 1991: Evaluation of fagocytic function of canine peripheral polymorphonuclear leukocytes by whole blood chemiluminiscence. J Vet Med Sci 54: 63-67 
McEWAN AD, FISCHER EW, SELMAN IE, PENHALE WJ 1970: Turbidity test for estimation of immune globulin levels in neonatal calf serum. Clin Chim Acta 27: 155-163

MILLER WH 1991: Deep pyoderma in two German Shepherd Dogs associated with a cell-mediated immunodeficiency. J Am Anim Hosp Assoc 27: 513-517

NICKOLOFF BJ, STEVENS SR 2006: What have we learned in dermatology from the biologic therapies? J Am Acad Dermatol 54: 143-151

RICHTER J, PROCHÁZKOVÁ J 1986: Lysozym - fotometrická metoda. In: PROCHÁZKOVÁ J, JOHN C. (Eds) Vybrané Diagnostické Metody Lékafiské Imunologie. Avicenum, Praha, 109 p.

SAFAI-KUTTI G, FERNANDES Y, WANG B, SAFAI RA, GOOD NK, DAY MJ 1980: Reduction of circulating immune complexes by calorie restriction in (NZB x NZW) $\mathrm{F}_{1}$ mice. : 293-300

SAS Institute Inc. 2005: Statistics and Graphics Guide. Release 6. SAS Campus Drive, Cary, NC, USA

SHEARER DH, DAY MJ 1997: An investigation of phagocytosis and intracellular killin of Staphylococcus intermedius by canine neutrophils in vitro. Vet Immunol Immunopathol 58: 219-230

SCOTT DW, MILLER WH, GRIFFIN CE 2001. In: Small animal dermatology. $6^{\text {th }}$ edition, W. B. Saunders, Philadelphia, pp. 230- 232, 274-335, 647-650

TOMAN M, SVOBODA M, RYBNÍČEK J, KREJČÍ J, FALDYNA M, BÁRTA O 1997: Immunosuppression in dogs with pyoderma and/or demodicosis. Vet Med-Czech 42: 299-306

TOMAN M, SVOBODA M, RYBNÍČEK J, KREJČÍ J, SVOBODOVÁ V 1998: Secondary Immunodeficiency in dogs with enteric dermatologic, infectious or parasitic diseases. J Vet Med 45: 321-334

VĚTVIČKA V, FORNUSEK L, KOPEČEK J 1982: Phagocytosis of human blood leukocytes: a simple micromethod. Immunol Lett 5: 97-100

WISSELINK MA, VAN KESSEL KPM, WILLEMSE T 1997: Leukocyte mobilization to skin lesions, determination of cell surface receptors (CD11b/CD18) and phagocytic capacities of neutrophils in dogs with chronic deep pyoderma. Vet Immunol Immunopathol 57 : 179-186 